\section{Bicentenary of the University of Pennsylvania}

The University of Pennsylvania, Philadelphia, celebrates this year the bicentenary of its foundation. During July and August, the laboratories, museums and libraries of the University, the Morris Arboretum and other places of interest will be open to visitors, and the principal celebrations will take place during the week September 15-21. The week will open with addresses by well-known authorities, which are intended not only to serve as tributes to the University of Pennsylvania but also to focus attention upon the contributions which higher education has made and can still make to the betterment of mankind. Among delegates announced from Great Britain are Sir Henry Dale, Sir Thomas Lewis, Sir William Beveridge, Prof. A. J. B. Wace, Sir Robert Robinson and Dr. C. S. Myers. Some forty symposia and conferences have been arranged to follow the general sessions. In connexion with the celebrations, a Bicentennial Fund has been inaugurated, and by the early part of April, more than four million dollars had already been subscribed, of which a half had been contributed by alumni of the University.

\section{Announcements}

Sir Arnold Wilson, K.C.I.E., C.S.I., C.M.G., M.P., distinguished for his administrative work in India and Persia, chairman of the Industrial Health Research Board during 1926-33, has been reported by the War Office as missing.

Sir Frank E. Smith, F.R.S., director of instrument production in the Ministry of Supply has, in addition, been appointed controller of telecommunications equipment with full authority, by the Minister of Aircraft Production.

Mr. J. Davidson Prate has been appointed an additional deputy director-general for chemical research, experiment and development in the Ministry of Supply. Mr. Davidson Pratt has been since 1928 general manager of the Association of British Chemical Manufacturers, who have now agreed to second him for his present appointment.

THE joint committee of the Royal Society of Edinburgh, the Royal Physical Society and the Royal Scottish Geographical Society has awarded the Dr. W. S. Bruce Memorial Prize (1940) to Mr. Brian Roberts, Emmanuel College, Cambridge, for his valuable work in survey, ornithology and general biology in the north and south polar regions.

THE following appointments and promotions in the Colonial Service have recently been made: $R$. W. Rayner, plant pathologist, Kenya ; C. B. Garnett, agricultural officer, Tanganyika Territory, to be marketing officer, Nyasaland; N. Humphrey, agricultural officer, to be senior agricultural officer, Kenya ; E. B. Martyn, botanist and plant pathologist, British Guiana, to be plant pathologist, Jamaica ; A. J. Wakefield, director of agriculture, Tanganyika Territory, to be inspector general of agriculture in the West Indies ; R. H. Tyrwhitt-Drake, director of surveys, Zanzibar, to be director of surveys, Kenya; G. B. Simmins, senior veterinary research officer, to be chief veterinary officer, Palestine.

Mr. Norman Nevilus will head an expedition of nine on a trip down the Green and Colorado Rivers, leaving Green River, Wyoming, on June 20, and arriving at Boulder Dam about August 25. The group will travel in three specially designed boats and make botanical and geological observations and collections in the little-known Canyon country. Dr. Hugh C. Cutler, of Washington University, is in charge of botanical research, and Mr. Nevills of the geological work.

The Goethe Medal for Art and Science has been awarded to Heinrich Ewald Hering, formerly professor of physiology in the University of Cologne.

BY a recent decree the State has authorized the creation in French universities of faculties of pharmacy and the consequent granting of doctorates in pharmacy. By this action universities will rank pharmacy with the other four faculties-arts, law, sciences and medicine. Prior to this decree aspirants to high qualifications in pharmacy were awarded either a "doctorat d'Université, Mention pharmacie" or a "diplôme supérieur de pharmacie".

The Council of the Royal Aeronautical Society has accepted an offer from Mrs. G. Alston to found a prize in memory of her husband Peter Alston who was killed in a flying accident on February 16, 1939. The prize, an annual one of approximately $£ 5$ in value, will be awarded for work aiming at the improvement of the safety of aircraft and particularly at improvement in stability and control, and such award is open to a student and/or graduate of the Society.

The New York Academy of Sciences announces three prizes offered by Mr. A. Cressy Morrison, to be known as the A. Cressy Morrison Prizes I, II and III, all of which will be awarded in December 1940. Prize I, of five hundred dollars, will be awarded for the best paper on solar and stellar energy. Prizes II and III will be awarded for the best papers on a scientific subject included within the field of the Now York Academy of Sciences and its affiliated societies. The competition for Prize I is open to all. Prizes II and III are limited to members of the New York Academy of Sciences and affiliated societies, but non-members may become eligible by joining one of these organizations before the closing date. Further information can be obtained from the Secretary, New York Academy of Sciences, Central Park West at 79th Street, New York City.

When dealing with Dr. Haddon's second expedition to the Torres Straits (NATure, June 1, p. 849) reference was made to Haddon's visit to New Guinea "with Ray and Seligman" ; Prof. Seligman informs us that this should read "with Ray, Wilkin and Seligman". 